\title{
Competence-based approaches in organizational and individual context
}

\author{
Bruno Škrinjarić (iD ${ }^{1 凶}$
}

With an increasing pace of digitalization, automatization, and robotization, firms need to quickly anticipate new consumer values, trends, and needs and adjust their production, thus requiring constant adaptation of competences and competence-based models. This review: (1) briefly outlines the development of competence-based models; (2) presents difficulties when defining and delineating differences between competences, skills, and abilities; (3) presents the main challenges of competence measurement; (4) presents recent findings of competence-based models in organizational and individual context; and (5) highlights challenges these models are likely to encounter in the future. To this end, a non-systematic literature review was carried out to summarize relevant published research studies and to define future research directions. Results show that further competence-based research should focus on generalizing the findings by looking at various groups of workers and industries, expanding the set of competences used in the analyses, using different definitions of key competences, and developing alternative models to assess their impact on performance. Such research would allow to better assess employees' preparedness in terms of competence requirements, as well as to identify the most critical gaps and opportunities for the formal educational system and as part of on-the-job training.

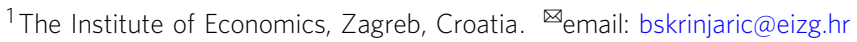




\section{Introduction}

$\mathrm{n}$ increasing pace of digitalization, automatization, and robotization, features of the fourth industrial revolution, has emphasized the need for firms to quickly anticipate new consumer values, trends, and needs, to be more flexible in their production processes, and to translate those into product offerings (Lazarova and Taylor, 2009). Simple and monotonous processes are being automated, while other processes become more complex and intertwined, thus shortening the shelf-life of employees' existing competences (Grzybowska and Łupicka, 2017; Hecklau et al., 2016; World Economic Forum, 2016) and putting constant pressure for new competence acquisition or improvement of previously mastered ones. Although these processes hold great promise for future prosperity and job creation, they also pose major challenges, especially in human resource management, requiring consistent proactive adaptations.

This review is focused on presenting the development and application of competence models in the organizational and individual context. The reasons for this division into organizational and individual contexts are twofold: (1) as shall be later elaborated in section "Development of competence-based models", competences have dual origins, where one approach is more organization-based (the UK approach) and the other is more individual-based (the US approach); and (2) this also stems from the summation of work done within the body of literature, where some authors highlight the importance of competences for the entire organization, while others focus on their role in individual outcomes. Organizations (employers) use competence models to select individuals with a particular set of competences (competence inventory) for the positions requiring that particular competence inventory in order to boost overall efficiency and reduce potential on-the-job training costs. Moreover, for existing employees, these competence requirements represent a need for designing on-the-job training practice (Husain et al., 2010). On the other hand, from an individual (employee) point of view, competence models serve as guidelines to highlight competences currently required on the labor market. Individuals can use this information to increase their employability and wages and to reduce their job search costs.

The review question for this paper is the following: "What are the implications of the competence-based approaches for organizations and individuals?" This review question encompasses: (1) how the dual nature of the origins of competences reflects their current definition and differences to skills or abilities; (2) what strategies are most commonly used for their measurement and what their potential problems are; (3) how competence-based models are integrated into decisions made by organizations and individuals; and (4) what the future challenges regarding the usage of these models are.

Based upon these questions, the aims of this review are the following: (1) to summarize the origins of the competence-based approaches in individual and organizational contexts, respectively, and list most important milestones in its development; (2) to present most important difficulties when defining competences and when delineating differences between competences, skills, and abilities; (3) to present different methods for identifying and measuring competences and certain limitations most practitioners face in such endeavors; (4) to present recent findings of competence-based models in organizational and individual context; and (5) to highlight further challenges this field is likely to encounter in the future.

To that end, this paper uses a non-systematic literature review (McDougall, 2015), also defined as a narrative style literature review (Ferrari, 2015). The main goal of this method is to identify a gap in the literature, to summarize relevant published research studies, and to define future research directions that have not been previously addressed (Ferrari, 2015). Since the present study aims to contribute to the existing theory by analyzing and describing theoretical and empirical findings of previous research studies, the applied narrative literature review approach, which is more common in management and economics disciplines, can be considered valid. To assure the objectivity of the narrative literature review approach, as well as the structural consistency with the previous overview articles, this review follows one of the widely adopted standard patterns of a narrative literature review explained by Green et al. (2006). Literature searches were conducted using the Google scholar search engine and extracted from Scopus, Web of science, ERIC, ScienceDirect, and JSTOR databases using relevant keywords related to competences in organizational and individual contexts. The following keywords were used as starting search terms: 'competence', 'competency', 'competence measurement', 'competence vs. competency', 'competences and wages', 'competences and employability'. Since competences are a multidisciplinary concept, the inclusion criteria referred to academic papers from various scientific areas, ranging from psychology and sociology to economics. The exclusion criteria referred to papers not available through the fulltext option and those not written in English. The authors made a conscious, joint, and iterative decision to consider each identified paper as relevant and to include them in this review. Moreover, additional papers were identified from reference lists from the retrieved papers. Finally, each literature source cited in the text has been listed in the References section at the end of the paper.

This work enriches the current literature in several ways. Firstly, recent technological advances constantly demand different labor competences, putting more emphasis on competence fit as opposed to conventional practices of hiring for a fixed job position (Rodriguez et al., 2002). In addition, an increasing number of (educational) policies and curricula assign greater orientation towards learned outcomes of education (competences) as opposed to time spent in education, and to more goaloriented as opposed to knowledge-absorptive educational system. Therefore, as an increasing number of practitioners and researchers has been focusing on competence-based models, this review provides an important stepping-stone for any such inquiry. Secondly, there are still misunderstandings regarding what competences encompass. This mix-up is emphasized by frequent synonymous use of terms like 'competence', 'competency', 'skill' or 'ability'. This review delineates origins and differences between these terms. Thirdly, there is still confusion on how to accurately identify and measure competences. This review provides a brief survey of different quantitative and qualitative methods most frequently used in competence measurement and analysis. Finally, as (employer-employee) competence match represents a crucial part of fourth industrial revolution processes, this review provides an avenue for future research on competence analysis at the organizational and individual level, respectively.

This review starts with a short overview of the development of competence models and issues regarding their definition in section "Development of competence-based models". Different approaches used to identify and measure competences are reviewed in section "Brief survey of different quantitative and qualitative methods used for competence measurement and analysis". Sections "Competence-based approaches in organizational context" and "Competence-based approaches in individual context" give an overview of how the competence-based approaches are used in the organizational and individual context, respectively. Section "Combining organizational and individual contexts: effects of competence mismatch" then combines these two contexts and tackles competence mismatch between employers and employees. Section "Conclusion" concludes. 


\section{Development of competence-based models}

Important milestones of competence-based models. Competencebased models (also known as competence-based approaches) represent a descriptive tool that identifies the competences needed in an organization (Chung-Herrera et al., 2003; Hecklau et al., 2016); they are a vital factor in integrating education and training with labor market needs, thus promoting mobility for individuals, especially for workers faced with job insecurity (Van der Klink and Boon, 2002). These models draw their origins from the latter half of twentieth century both from the US (the more individual-based approach) and the UK (the more organizational-based approach) and have recently become increasingly important in aligning labor market needs with educational and training curricula. Based on a thorough literature survey, four important milestones of competence-based approaches development have been identified.

Competence-based model foundations in individual context were laid by McClelland (1973), starting from a perspective that classical intelligence and ability tests only predict academic success and do not envisage essential life events and outcomes. As a result, all correlations and causations based on such metrics suffer from cultural and social bias. Having in mind a wider context, he suggested to start observing successful and less successful job performers and determining how the former differ from the latter. Thus, the first milestone in the competence-based models was to recognize that classical intelligence and ability tests cannot predict how successful and/or efficient a person will become throughout their career, and that success should be measured in a wider context, by directly comparing successful and less successful workers.

The second important milestone came a decade later with an empirical design that put McClelland's (1973) arguments to a quantitative test. Boyatzis (1982) conducted a study on 2000 managers at various corporate levels from 12 different organizations, aiming to identify characteristics determining their success. Assuming that the efficiency of an organization depended on its managers' characteristics, he compared managers' behavior in critical situations and identified over 100 competences, dividing them in two groups: (i) basic competences (e.g., logical thinking, self-esteem, spontaneity), and (ii) superior competences (e.g., efficiency orientation, group process management, persistence, adaptability).

The next important milestone was the realization that competences are also important from the point of view of organizations. From the discussion above, it is evident that both McClelland (1973) and Boyatzis (1982) put the individual in the center of analysis and focus on competences in individual context. On the other hand, Prahalad and Hamel (1990) start off at the organizational level and introduce core (key) competences as the capacity to coordinate diverse production skills and integrate various streams of technologies across organizational boundaries. These core competences, from the point of view of organizations, should: (i) provide potential access to a wide variety of markets, (ii) contribute to the customer, and (iii) be difficult for competitors to imitate. Their study corresponded to the one by Boyatzis (1982), who looked at successful and less successful individuals, only this time the subject of analysis were two similar organizations that took different paths-the first one structured its business around a group of core competences, while the other one structured it around strategic business units. Their results indicate that the latter model under-invests in core competences and limits innovation, and show the former to be more successful.

The final milestone comes from uniting the individual and organizational contexts of the competence-based models under a single umbrella. Robertson et al. (2003) present a contemporary competence-based model, where they distinguish four different determinants of successful job performance: (i) competence potential, (ii) competences, (iii) context, and (iv) outcome.
Competence potential encompasses individual characteristics needed for the realization of certain outcomes, which include dispositional potential (traits, motives, values) and other accomplishments (knowledge, skills, qualifications, and experience). Competences are a set of desired behaviors, defined through outcomes to which these behaviors are directed. The difference between these two terms arises from a third elementcontext-referring to organizational characteristics and social relations within organizations determining desirable behaviors and outcomes. A final set of variables deals with desirable results and outcomes individual behavior is directed towards. A good example of this holistic approach to competence-based modeling is that of Hecklau et al. (2016), who concentrate on the role of contemporary human resource management. Their approach consists of three vital steps: (i) identification of emerging challenges (divided into political, economic, social, technical, environmental, and legal factors), (ii) deduction of competences to face those challenges (aggregated into technical, methodological, social, and personal competences), and finally, (iii) visualization of required competences development levels.

From 2000 onwards, competence-based human resource management has become widespread in the processes of selection, retention, and remuneration. Delamare le Deist and Winterton (2005) list several factors for the rising popularity of this approach, among which they emphasize: (i) shift from the traditional supplydriven (knowledge-absorptive) to a more demand-driven (goaloriented) educational system, (ii) increase in adaptive training, work-based and non-formal learning, and (iii) greater orientation towards learned outcomes (irrespective of acquisition method), as opposed to outcomes in terms of time spent in education, providing 'ladders' for those who have had fewer educational opportunities, but have nonetheless developed required competences.

While this subsection served only to briefly summarize important milestones in the competence-based approaches, competence analysis on both organizational and individual contexts will be reviewed in sections "Competence-based approaches in organizational context" and "Competence-based approaches in individual context", respectively. Section "Combining organizational and individual contexts: effects of competence mismatch" then combines these two approaches and deals with the competence mismatch between the competence requirements of employers and the competence development of employees.

"Competency" vs. "Competence" debate. Although the debate about individual and organizational competences has gained in importance over the last two decades and has expanded beyond academia, the literature has yet to achieve consensus on basic conceptual definitions. One of the major challenges in competence literature is defining the term as abstract as competence (Čiarniené et al., 2010; Lichtenberg et al., 2007). Not only are there multiple definitions, but every author has his or her own image of what they are, what they include, and how to measure them. This confusion is deepened by the often-interchangeable usage of two terms-'competence' (plural 'competences') and 'competency' (plural 'competencies'). Origins of this debate can be traced to the fact that 'competency', in the American sense, complements 'competence', as used in the UK occupational standards.

The term 'competency' originated in education to describe trainee-teacher behaviors but was later adopted in the management domain in the US, referring to sets of behaviors a person must display to perform the tasks and functions of a job (Moore et al., 2002). Competencies are not seen as the task of the job, but rather that which enables people to do the task (Kurz and Bartram, 2002; Mitchelmore and Rowley, 2010). Thus, in line with McClelland's (1973) and Boyatzis' (1982) individual- 
oriented approach, the American school emphasized the underlying characteristic of a person in their concept of competency. On the other hand, the UK-based approach put more focus on 'competence' - the ability to apply knowledge, understanding, and skills in performing up to the standards required in employment. The term competence was first coined by White (1959) to describe personality characteristics responsible for effective interaction (of the individual) with the environment (workplace), associated with superior performance and high motivation. Thus, in line with Prahalad and Hamel's (1990) organizational-oriented approach, the focus here is on task-oriented analysis, which reflects expectations at the workplace. Competence is seen as a description of an action, behavior, or outcome, which an employee should be able to demonstrate (Cheng et al., 2005).

The debate between these two approaches can be summarized by saying that the definition of competence diverges into two distinct directions: a collective approach, centered on requirements for organizational performance, and an individual approach, centered on individual behaviors and outcomes, and most definitions fall somewhere between these two extremes. As a case of the former, organizational (UK-based) approach, authors focus on the role of competences in final outcomes by defining them as '... measurable working habits and personal skills that are used to achieve a work goal' (Green, 1999, p. 5) or as '... sets of behaviors that are instrumental to achieve the desired results and outcomes' (Kurz and Bartram, 2002, p. 229). As for the latter, individual (US-based) approach, authors shift attention to individuals themselves and define competencies as '... motives, traits, self-concepts, attitudes or values, content knowledge, or cognitive or behavioral skills-any individual characteristic that can be measured or counted reliably, that can be shown to differentiate significantly between superior and average performers, or between effective and ineffective performers' (Spencer and Spencer, 1993, p. 4) or as individual dispositions to selforganization, which include cognitive, affective, volitional (with deliberate intention), and motivational elements, they are an interplay of knowledge, capacities and skills, motives and affective dispositions' (Rieckmann, 2012, p. 131). This polarization of the definition of competence is also reflected in sections "Competence-based approaches in organizational context" and "Competence-based approaches in individual context" of this review, with separate analyses of competence-based models in the organizational and individual context, respectively.

In addition to the 'competence' vs. 'competency' debate, other terms like 'skills' or 'abilities' are all inter-related and oftentimes interchangeably used to describe competences (Jackling and De Lange, 2009). Thus, it is important to briefly outline the differences between skills, abilities, and competences. Sonntag and Schmidt-Rathjens (2004) define skills as automated components of tasks, which are undertaken with a relatively low mind control and include routine jobs. While skill concerns the execution of a single task, competence deals more with the execution of a whole series of different tasks in a certain (occupational) domain. Abilities are defined as all kinds of innate characteristics of a person that are necessary to perform tasks and services, and they are thought to be, to a greater extent, something a person is born with. On the other hand, competences can be learned within a favorable environment (OECD, 2005) and, unlike abilities or talents, can be learned and developed in adulthood (Boyatzis, 2008). In summation, competences are strongly associated with mastering complex situations (contradictory information, informal collaboration, and abstract, dynamic, and highly integrated processes) demanded by modern-day employers and transcend the level of skills and/or abilities, given their synergistic and inter-related nature. This is further corroborated by $\operatorname{OECD}(2005$, p. 4), who define competences as '.. more than just knowledge and skills. It involves the ability to meet complex demands, by drawing on and mobilizing psychosocial resources (including skills and attitudes) in a particular context', and Belasen and Rufer (2007), who also emphasize that competences transcend simple skills or abilities and actually encompass both of those. In fact, the most frequently used method in measuring competences (as will be described in section "Identifying and measuring competences") is the aggregation of multiple skills/abilities into competences.

Finally, several different competences can be grouped under the same category, which are most often divided into: (i) domainspecific, and (ii) general (generic) competences (e.g., Biesma et al., 2008; Leoni, 2011, 2012). The former cluster consists of theoretical knowledge and methods specific to a certain domain, while the latter includes higher cognitive (such as learning competences, analytical competences, problem-solving competences) and interpersonal (such as team working, planning, and organizing, and decision-making competences) competences that can be used at any workplace. This review paper is not specifically focused on either of those nor on reasons for such a division, but rather on their usage in individual and organizational context.

\section{Brief survey of different quantitative and qualitative methods used for competence measurement and analysis}

Measuring competences is vital to both researchers and practitioners, as any competence-based models will heavily depend on it. Approaches used vary in terms of different definitions and methods applied, which accounts for inconsistent results across different studies. The most common technique for measuring competences is through questionnaires with a list of working behaviors, where respondents are required to tick if, and to what extent, these are implemented (Leoni, 2011). This list of behaviors should aim to cover the whole range of work actions in each context, paying attention to refer to the smallest units of observations that are both directly comparable and sufficiently distinguishable.

Identifying and measuring competences. This subsection describes a variety of different methods for identifying and measuring competences. Broadly speaking, these methods can be divided into quantitative and qualitative techniques. In terms of the former, the most frequently used are different aggregation methods (like factor analysis method or clustering method), while for the latter, the most frequently used methods are Delphi group rounds method, panel studies method, focus groups method or semi-structured interviews method.

Quantitative aggregation methods in identifying and measuring competences are based on the notion that it is not easy to view individual competences as single entities (Jackson, 2009). Thus, all these methods start off with a list of different skills/abilities, which are then aggregated or grouped into competences. The intuition behind this approach is to reduce the dimensionality of datasets as list of different skills/abilities can be quite extensive and highly correlated. Most methods used include the factor analysis method (Ahn et al., 2012; De Vos et al., 2011; García-Aracil and Van der Velden, 2008; Leoni, 2012; Van der Heijde and Van der Heijden, 2006; Yusof et al., 2012) or cluster analysis method (Gabe et al., 2012; Kusumastuti, 2014) to compress highly correlated skill/ability items into several competences. Van Loo and Toolsema (2005) take a slightly different approach - they start by estimating the contributions of each skill to all other skills before summing up these contributions and defining key competences if this sum exceeds certain threshold. Since a concept such as competence lacks a distinctive measuring unit, in virtually every quantitative study competences are measured using Likert scales. 
On the other hand, qualitative methods of identifying and measuring competences include several different qualitative-based techniques, such as Delphi group rounds method, panel studies method, focus groups method or semi-structured interviews method. Owen (2001) explores competences required by potential employers of geography graduates by organizing a focus group of six managers who were asked to describe their perfect employee, which was then translated into key competences. Rieckmann (2012) performs Delphi group rounds with experts from Europe and Latin America to explore competences crucial for sustainable development. Other studies use previous literature to define a starting list of competences, which is then amended based on their professional experience or using semi-structured qualitative interviews with industry professionals and, in some instances, recruitment agencies and the university faculty (Azevedo et al., 2012; Hodges and Burchell, 2003; Pan and Perera, 2012). Studies of this kind were performed for public health workforce (Allegrante et al., 2001; Biesma et al., 2008; Kreitner et al., 2003), HR managers (Jamshidi et al., 2012), R\&D managers (Dreyfus, 2008), academic librarians (Mahmood, 2003), managers in higher education (Spendlove, 2007), tourism industry (Zehrer and Mossenlechner, 2009), construction industry (Ahn et al., 2012), automotive and pharmaceutical industry (Grzybowska and Łupicka, 2017), hightechnology manufacturing (Wang et al., 2004), lodging industry (Chung-Herrera et al., 2003), industry 4.0 sectors (Hecklau et al., 2016), and the nursing sector (Cowan et al., 2008). However, although these qualitative approaches are very useful in identifying perceived key competences, they preclude firm conclusions and have limited representativeness.

Although rare, competences have also been identified and measured using experimental design. One such study is that of Biesma et al. (2007), who utilized explicit questions and choicebased conjoint analysis method to measure competence preferences of employers for Dutch public health graduates. Their methodology involved defining different hypothetical profiles of workers (each with different combinations of competences), which was then presented to employers who had to assess the employability of workers based on these competences.

Limitations in competence measurement and analysis. There are several challenges and limitations in identifying and measuring competences-something that manifests itself differently in different contexts, changes and evolves over time, and is not directly observed.

The first group of limitations is tied to the traditional competence-measuring approach, where competences acquired are equated with educational (qualifications) attainment. However, equal educational (qualifications) attainment can lead to a very different competence quantity and/or quality, which can differ in their market value (Desjardins and Rubenson, 2011) or may not be fully utilized due to labor market mismatches. In fact, Murray, Owen, and McGaw (2005) found that in some countries returns to competences are far higher than returns to education, suggesting that education is only rewarded if it leads to acquisition of competences needed on labor market. Several studies have confirmed a very weak correlation between qualifications mismatch and competences mismatch (Allen et al., 2013; Mavromaras et al., 2009). In addition, acquisition of competences, unlike abilities or talents, continues throughout adulthood long after formal schooling is completed, through learning-at-work and accumulation of work experience (Biesma et al., 2008; Boyatzis, 2008; Green and Riddell, 2013).

The second limitation is concerned with (mis)measurement of the competences as a self-reported measure, thus resulting in bias associated with a situation when respondents rate their characteristics too positively. Some authors reduce this bias by measuring employees' competences both directly from the employees and from their supervisors (Van der Heijde and Van der Heijden, 2006). On the other hand, Leoni (2012) argues that workers are quite capable of assessing their own competences, and any self-appraisal error, either over- or under-estimation, is assumed to be unrelated to other variables. Other studies justify the self-reporting approach by arguing that workers' assessments were very similar to those made by external observers and suggest that bias can be curbed to a minimum simply by paying attention to the language used in questionnaires-by asking respondents not for an assessment of the competences they possess but for the degree of competences they must demonstrate on their job position (Spenner, 1990). Additionally, most of the methods used for identifying and measuring competences suggested in section "Identifying and measuring competences" are of a suggestive nature, i.e., these measures only observe what competences someone thinks they have developed and do not allow for a direct demonstration of competences in specific exercises (e.g., making a presentation to an audience, leading a team in a work project) (Azevado et al., 2012).

Another group of limitations concern the generalizability of the findings, which are more pronounced in a qualitative type of assessment due to nature of such research. Two issues emerge here: (i) small sample sizes and (ii) an overemphasized focus on graduates. Examples of the former include Dreyfus (2008), who uses 35 respondents to explore highly effective performance of R\&D managers; Chiru et al. (2012), who use a sample of 44 companies to assess the key competences for the agro-food sector; Zehrer and Mossenlechner (2009), who use 48 employers to define key competences for the tourism sector. In terms of the latter, majority of the studies have focused solely on graduates (Bailey and Ingimundardottir, 2015; Chiru et al., 2012; Husain et al., 2010; Van Loo and Toolsema, 2005), thus compromising the generalizability of the findings for employees with longer tenures (Haider and Solon, 2006).

The fourth issue of contention and debate in the competencebased literature is much more general, and it concerns the casual link between competences and their development on the one side and managerial and/or organizational performance on the other. The main concern here is the direction of causality, which stems from the fact that many studies have neither a prior assumption about the direction of causality between competence and the measured outcome nor a panel dataset (De Vos et al., 2011; Van Loo and Toolsema, 2005). Hence, most of such results can only be interpreted in terms of correlations or associations rather than causations.

Finally, since most competence-based methods are based on behavior in critical situations until now, current models are exposed to dangers of shaping the future needs of organizations based on what has worked in the past. For example, productive and less productive workers until now may be different in terms of some currently irrelevant characteristics that may grow in importance in the future. Even more so, by only hiring workers based on the characteristics of those productive workers until now, an organization is in danger of creating their clones, thus diminishing its workforce diversity and jeopardizing the potential for creativity and innovation (Sparrow and Bognanno, 1993). Competences are dynamic by their very nature, and all competence identifying or measuring methods should incorporate forward-looking component.

In summation, there are several quantitative and qualitative methods for identifying and measuring competences. Quantitative methods usually allow for greater datasets but are mostly based on competence self-evaluation. On the other hand, qualitative methods allow for a greater fine-tuning in competence identification and measurement but usually suffer from limited generalizability. Further competence-based research should focus on generalizing the findings by looking at various groups of 
workers and increasing the size of the dataset, expanding the set of competences used in the analyses, using different definitions of key competences, and developing alternative models to assess their impact on performance. Subsequent research on competence development should also utilize longitudinal design to provide additional insights into where and how individuals develop competences and whether they align with industry expectations. If a number of these models corroborate the direction effect of the same competence, it would imply a significant advance in the relevance of competence-based models and their application in shaping educational curricula, government policies, and career management practices.

\section{Competence-based approaches in organizational context}

Research on firm performance can generally be divided into two broad categories, highlighting either external or internal aspects of the firm. Studies in the former group typically examine the impact of different (government) policies on firm performance, starting with a premise that a lack of financial and/or training support is the greatest obstacle to the success of firms (Srhoj et al., 2021). However, these studies neglect the important contribution of business owners and workforce as the ones creating added value to account for final outcomes. On the other hand, the latter group of studies emphasizes the role of internal organization resources-competences, culture, and organizational behavioron the performance of firms (e.g., Ananiadou et al., 2004; Markman, 2014; Psacharopoulos and Schlotter, 2010). Studies of this type, however, are very scarce and those that exist suffer from a variety of methodological weaknesses.

A case can be made that entrepreneurs' competences are the most important factor of the success of organizations, particularly in SMEs. Research of this kind originated from the Theory of Entrepreneurial Competency (Bird, 1995) to describe the link between the behaviors and attributes of business owners for future business success, arguing that those who hold key positions in an organization have a significant influence on the organization's success. Gerli et al. (2011) use a sample of 97 Italian SMEs to investigate the impact of entrepreneurial owners' competence portfolio on business performance. Their results suggest that competences like efficiency orientation, planning, persuasiveness, self-confidence, organizational awareness, directing others, teamwork, leadership, and benchmarking are related to a higher firm performance. Mitchelmore and Rowley (2010) stress the importance of the dynamic nature of competences, i.e., that the greatest challenge of entrepreneurs is to identify and modify required competence inventories as firms move through development stages. Man et al. (2002) suggest that, in the long term, ensuring adequate entrepreneurial competences is more important than directly providing businesses with more resources or securing a positive external environment. Furthermore, they argue that entrepreneurs need a good balance between various competences, given their strong interaction and their descendants (e.g., lack of organizing competences hinders the development of organizational capabilities, which in turn limits the use of strategic and commitment competences). Entrepreneurial competences bear an even greater importance in a negative external environment, as indicated by Hazlina Ahmad et al. (2010), who investigated their impact on firm performance in Malaysia. Using a sample of 212 SME owners, they showed that entrepreneurial competences were strong predictors of business success, especially evident in hostile and dynamic environments, indicating that entrepreneurs can to some degree mitigate negative environment impacts by equipping themselves with appropriate competences.

Moving on to the effects of workforce competences on firm performance, Stevens (2007) found considerable heterogeneity across industries in how competence shortages affect employment practices-some industries experience only intermittent competence shortages in the workforce, while others, like the metal manufacturing and metal products sector, experience pro-cyclical competence shortages. This heterogeneity suggests that industry-specific competences play a part in explaining labor market behavior and influence the employment practices of firms. Benson and Lawler (2011) investigated employees' high-involvement practices (i.e., general competences) such as teamwork, employee development, gain sharing plans, and participative leadership in the US, and have positively associated them to firm performance. However, improving individuals' general competences may sometimes hamper productivity growth if job positions are not designed to cope with that. Utilizing International Adult Literacy Survey (IALS) data, Murray et al. (2005) note that improving general competences might increase competence inventory mismatch for positions-on the one hand, there are medium and high-skilled workers occupying lowpaying positions (thus suffering a wage penalty), and on the other, there are low to medium skilled workers who are well paid (thus enjoying a wage premium). Green et al. (2002) nicely illustrate this problem for the UK, using a university graduate employed in a secretarial role (case of over-education) where her competences will be under-utilized, thus resulting in a lower productivity level and lower wage than in a 'graduate-suited job'. Felstead et al. (2007) present the scale of this problem in the UK, where 2 out of every 5 workers reported they were over-qualified for their jobs, reflecting a large increase in the supply of university graduates, but also casting doubt on the extent to which employers have created jobs that demand high skill levels. Also, Le Mouel and Squicciarini (2015) use PIAAC data to develop a methodology for the measurement of employment and investment in organizational capital (OC) in 20 OECD countries. OC was defined as firm-specific organizational knowledge resulting from the performance of tasks affecting the long-term functioning of firms (e.g., developing strategies, organizing, planning and supervising production, and managing human resources), and estimates at the aggregate level suggest the share of OC occupations in total employment to range between $9.5 \%$ (Denmark) to $26 \%$ (United Kingdom), with an average of $16 \%$.

Workforce competence inventories need not directly impact firm performance, but rather act as a medium between other factors of production and final outcomes. Forth and Mason (2006) investigated returns on competences of ICT companies in the UK and found that employees' ICT competence shortages were correlated with negative firm performance, albeit indirectly-these competence deficiencies restrict companies both in terms of ICT adoption and the intensity of use of ICTs once they have been installed, which then negatively impacts performance. Leoni (2012) analyses the extent to which competences (dependent on high-performance workplace practices) act as a mediating variable between a highperformance work organization and the economic outcomes of firms, and finds that development of such competences results in more efficient production. Ozkaya et al. (2015) compare US to Chinese firms and show that market knowledge competences are mediators of positive relationships between customer and competitor orientations and market-based innovation, especially in the US. On a similar note, Bai and Chang (2015) draw on stakeholder and institutional theory and investigate the impact of corporate social responsibility on firm performance on a sample of 295 Chinese manufacturing firms. Their results suggest that CSR is a source of competitive advantage that can enhance the marketing competences of firms, which in turn leads to superior performance. Similar results are also found for core-technology competences as crucial mediators in the relationship between technological diversification and firm growth (Kim et al., 2016) and for core competences as mediators between firm innovation output and performance (Gokkaya and Ozbag, 2015). 
Finally, some research stresses the complementarity between different competences, arguing that they fail to produce significant impact on the performance of firms in isolation, but succeed to do so when paired with other competences. Lokshin et al. (2009) base their analysis on the fast-moving consumer goods industry and find that organizational competences (e.g., team cohesiveness and slack time to foster creativity) improve the innovative performance of firms only when complemented with both customer and technological competences. In a similar study, Song et al. (2005) focused on complementarity between marketing and technological competences using a sample of 466 firms and concluded that only their synergetic effects led to improved firm performance in a high-turbulence business environment.

To sum up, given the growing importance of competences as a production factor, especially in the context of the fourth industrial revolution and an increasing pace at which competences become outdated, there seems to be a clear need for more empirical research, especially of longitudinal design, to better understand the role of competences in organizational performance. Such research would allow to better assess how well-prepared employees are for their positions in terms of competence requirements, as well as to identify the most critical gaps and opportunities that can be developed or strengthened both within the educational system and as part of onthe-job training. Furthermore, given the heterogeneity of different industries in terms of competence requirements and their impact on organizational performance, there can be no universal competence model to suit everyone. Thus, there is a need for greater cooperation between employers across all industries and researchers and/or policymakers to improve our understanding what competences are perceived to be most critical for effective work performance. These competence requirements then need to be compared against competence development of a current workforce and the effect of this proximity to organizational productivity should be analyzed.

\section{Competence-based approaches in individual context}

This section reviews the competence-based approaches in individual context. Competence impact on individual outcomes analysis relied mostly on a small number of specialized datasets, with the most popular being: European Working Conditions Survey (Bevan and Cowling, 2007); Adult Literacy and Life Skills (ALL) Survey (De Anda and Hernandez, 2008; Murray et al., 2005; Ryan and Sinning, 2009); International Adult Literacy Survey (IALS) (Ananiadou et al., 2004; Barone and Van der Werfhorst, 2011; Green and Riddell, 2013); Careers after Higher Education-A European Research Survey (CHEERS) (GarcíaAracil and Van der Velden, 2008; Mora et al., 2007), and Programme for the International Assessment of Adult Competencies (PIAAC) (Allen et al., 2013; Hanushek et al., 2015). When it comes to individual competence development impact analysis, two of the most-researched outcomes are employability and wage premiums, which are presented in the following two subsections.

Individual outcomes: employability. Focusing on the competences required on the modern labor market in OECD countries, Dickerson and Green (2004) suggest that future job growth is projected to be in services and knowledge occupations that usually require higher levels of general competences, as many lower-skilled jobs may be outsourced. These trends in OECD countries are governed by a rapid pace of technological advancement whose effects are magnified by the fourth industrial revolution. Focusing on technological development, Kirby and Riley (2006) use Labor Force Survey to estimate the impact of ICT on general and occupational-specific competence returns in different industries in the UK between 1994 and 2001. Their results suggest a greater premium on general competences in contrast to occupation-specific competences, arguing that the former set of competences is very useful in acquiring new skills for performing a broad range of activities, while the latter competences are less transferable between jobs, thus making them less desirable. However, this trend of increasing emphasis on general competences is not limited only to jobs requiring high levels of education for entry, like those in the ICT industry. Maxwell (2006), for instance, uses the Bay Area Longitudinal Study dataset to argue that even low-skilled jobs require English, math, communication, and problem-solving skills, along with certain job-specific skill sets. Similar results were found for West Germany, where SpitzOener (2006) showed that service tasks were also increasing in complexity, with analytical and interactive tasks overtaking routine and manual tasks.

Competence development is also indirectly associated with achieving personal outcomes. De Vos et al. (2011) use data from 561 employees of a Belgian company to investigate the relationship between competence development and career success as being fully mediated by employability. Utilizing the structural equation modeling technique, their estimations suggest that participation in competence development initiatives, as well as organizational support for competence development are positively associated with employability and thus with career success. Similarly, Bailey and Ingimundardottir (2015) explore the effects of students taking a free extra-curricular competence development program on their subsequent employability estimates and find positive associations. Van Der Heijde and Van Der Heijden (2006) perform a similar study in one Dutch firm, where they propose a competence-based model to measure employability based on a five-dimensional conceptualization complemented with specific and generic competences, which is found to be positively associated with both individual careers and firm outcomes.

However, the importance of a certain competence (in a very similar job) may differ in different social contexts. Finegold and Notabartolo (2010) mention an example of childcare and home health workers who, in France or in Scandinavia, are treated as professionals who require special qualification, while in the US their competences are unrecognized and unrewarded. Similarly, some jobs may only seem to require 'high-skilled' employees, when in reality, these 'high-skills' may only mask the ability to be able to cope with badly designed jobs and stressful working conditions (Appelbaum et al., 2003, Lloyd and Payne, 2008).

Individual outcomes: wage premiums. There are several studies linking individual competence inventory with wage premiums. By analyzing the National Longitudinal Study of the High School Class of 1972 and the High School and Beyond survey of 1980, Murnane et al. (2000) found that the increasing wage premiums between 1972 and 1980 were tied to an increase in cognitive competences. However, these effects may be heterogeneously distributed across the workforce, depending on various socio-economic aspects. Ananiadou et al. (2004) undertook an expansive literature review of work derived from the UK on the effects of literacy and numeracy on individual workers' wages and employment probability. Based on the analysis of IALS and the longitudinal National Child Development Study, they found both numeracy and literacy to be positively associated with higher wages, with the former have greater effect for men and the latter for women. In terms of return to specific skills, De Anda and Hernandez (2008, p. 240) utilize National Adult Literacy Survey data to show heterogeneous effects of literacy on different races and genders. They find 'the effect of literacy skills on the earnings of black males [in the US] is bifurcated: literacy skills seem to be more significant for less-educated black males than those with college degrees.' Black males are seen to benefit most from literacy competency, which is accompanied by a weekly earnings increase of $18 \%$. This is compared to the return on 
literacy skills for white females ( $13 \%$ earnings increase), white males (12\% earnings increase), and black females (9.8\% earnings increase). Kelly et al. (2010) look at the economic returns to different fields of study and the value placed on various job-related competencies, accumulated upon completion of higher education, in the Irish labor market. Their results suggest that competence returns vary across the wage distribution and that, apart from Medicine and Veterinary and technical graduates, competence-specific returns diminish as one moves up the earnings distribution. Adamchik et al. (2019) investigate the effect of English language proficiency competence on the wages of native full-time employees in Poland and show that monthly wages for those individuals with 'good' or 'very good' knowledge of English exceeded the wages of those with 'no English' by nearly $60 \%$ for men and more than $50 \%$ for women.

Not all kinds of qualifications and competences carry the same wage premium. Using UK data, Dearden et al. (2002) show evidence that academic qualifications, rather than vocational qualifications, correspond to higher earnings. They also performed an analysis of time required to obtain those qualifications and found that the return per year on vocational education moved, on average, towards those with academic qualifications. Van Loo and Toolsema (2005) analyze a sample of 1702 employed Dutch vocational graduates and the effect of five competences: problem-solving, independence, oral presentation/ speaking, accuracy/carefulness, and initiative/creativity. Their results suggest that independence, accuracy/carefulness, and initiative/creativity are positively associated with higher wages. Finally, some authors emphasize the complementarity of different competences towards the same outcome. Heijke et al. (2003) investigate the impact of general-academic, field-specific, and management competences on wage distribution of higher education graduates in northern Italy. They show that management competences have a direct positive wage-effect, while general-academic and field-specific competences do not show a direct pay off, but rather play a supportive role in the development of other skills that are in turn highly associated with higher pay off.

In conclusion to the competence-based approaches in individual context, we can state that competence models are currently given more attention than analysis in organizational context. This is undoubtedly due to the greater availability of specialized datasets on both the national and international scale that are mainly concerned with individual outcomes and allow for such analysis. However, these tests, aside from being costly and time consuming, require a separation from the workplace, and thus focus mainly on individuals' academic competences (like literacy and numeracy) and are not able to measure competences required at the workplace. Furthermore, the most common types of individuals in these assessments are early graduates and most analyses are based on associating competences they accumulated during university education to their labor market outcomes (García-Aracil and Van der Velden, 2008; Hanushek and Rivkin, 2012; Kelly et al., 2010; Leoni, 2011). There are, however, a few potential problems related to this approach-these estimates, based on early career earning, are likely to be downward biased as people with longer tenure show steeper earning growth (Haider and Solon, 2006) and it may also take some time to be compensated for individual competences. Even more so, all these analyses take the initial level of individuals' competences as a given, without investigating methods of their acquisition. Taking all this into account, one key aspect of competence analysis that is missing from the current body of literature is longitudinal design. By utilizing panel-type datasets, we would be able to observe returns on competences later in individuals' careers and, even more importantly, we would be able to track individual competence development throughout their lifetime.

\section{Combining organizational and individual contexts: effects of competence mismatch}

Modern-day employers have been increasing demand for new or updated qualifications and the intensity of new technologies usage, which caused instrumental shifts on the labor market. Shorter product life cycles and an increased pace of technological change caused many firms to become more market-driven and quicker in their adaptations to new customer needs (Yang et al., 2005). To achieve that, employers invest heavily in the human capital of workers to acquire the competences needed in the arena of globalization. However, since the cost of developing human capital is increasing, employers expect educational institutions to equip workers with competences required by the market without additional training from the industry (Husain et al., 2010). That is why more and more emphasis is given to the degree of (mis) match between employers' requirements and workers' acquisition of needed competences. Thus, in this section we are combining the competence requirements of organizations (employers) with the competence development of individuals and associating this mismatch to both organizational and individual outcomes.

Competence mismatch can have important economic consequences (Quintini, 2011). At individual level, it impacts job satisfaction and wages. At firm level, it dampens productivity and turnover growth and increases on-the-job search costs. Finally, at macroeconomic level, it increases the natural rate of unemployment and reduces GDP growth prospects. It is also important to stress that competence mismatch may emerge not just between contemporary competence requirements and developments but also between today's competence inventories and future competence requirements, which is why this topic is growing in importance.

Exploring competence mismatch, some authors have focused solely on graduates and evaluating their 'fit' for the labor market, i.e., how well the universities prepare them for future job challenges. Mora et al. (2007) use a Careers after Higher Education-A European Research Survey (CHEERS) data to estimate job satisfaction of higher education graduates and find that a surplus of qualifications and competences is one of the most relevant causes of job dissatisfaction. Using the same dataset, García-Aracil and Van der Velden (2008) also estimate competence gaps impacts on graduates' monetary rewards, indicating heterogeneous effects between different competence sets, i.e., they find that jobs with higher participative and methodological competence requirements are better paid (by 4 to $6 \%$ ). Nicolescu and Paun (2009) conduct a study in Romania to identify the extent to which graduates' expectations in terms of abilities and skills developed through higher education converge towards employers' requirements. Their results suggest that both graduates and employers have, to a large extent, similar types of expectations of higher education services, but the degree to which they emphasize different aspects varies. Graduates focus the most on getting practical knowledge, skills, and abilities, while employers put most focus on moral and psychological qualities of the individual, some of which are not in the university domain to teach in the first place. Hodges and Burchell (2003) perform a similar study for business graduates in New Zealand and find that traditional undergraduate degrees, which focus more on cognitive and technical development within a narrow discipline, may not be able to produce the well-rounded, multi-skilled, flexible, and adaptable graduates demanded by today's business organizations. Similar work was also done for other graduate fields (Azevedo et al., 2012; Wilton, 2008).

Other studies have gone a step further and investigated competence mismatch impact on wage premiums and job satisfaction. Allen and Van der Velden (2001) investigated mismatch impacts on labor market outcomes on Dutch university and tertiary vocational graduates. They exploited the Higher Education and Graduate Employment in Europe database, specifically the cohort who graduated in 1991, and studied their labor market situation seven 
years later, in 1998. Competence mismatches were found to be present among half of the graduates in each group and were found to be associated with a $6 \%$ decrease in wages and a $14 \%$ decrease in job satisfaction. Mavromaras et al. (2009) performed a similar study in Australia using Household, Income and Labor Dynamics survey and found that about $11.5 \%$ of working age employees in full-time employment were severely over-skilled and paid less, on average, than their equally skilled, well-matched counterparts. Green and McIntosh (2007) studied competence mismatch in Britain using the second Skill Survey conducted in 2001. The authors calculated that $35 \%$ of UK employees were over-skilled in 2001 and $13 \%$ were under-skilled, both of which negatively affected their wages, by 9.9 and 0.6 percent, respectively. Similar results were also found for Portugal (Vieira, 2005), Belgium (Verhofstadt et al., 2007; Verhaest and Omey, 2006), Denmark (Nielsen, 2007), Spain (Badillo-Amador et al., 2005), Sweden (Böhlmark, 2003).

Another stream of literature explored the effects of this mismatch on labor mobility and additional (on-the-job) training. Regarding the former, many studies have found that the mismatch is positively associated with labor mobility, as a possible means of reducing this problem (Allen and Van der Velden, 2001; Verhaest and Omey, 2006), while, regarding the latter, overskilled employees are less likely to take part in training programs than well-matched or under-skilled employees (Büchel and Mertens, 2004; Verhaest and Omey, 2006).

Research into the mismatch between workforce competence and employer requirements and its effect on firm performance is even scarcer. Forth and Mason (2006) investigated ICT competence mismatches and found an indirect negative impact on performance through the restrictions that such deficiencies place on ICT adoption and on post-adoption ICT use intensity. Shury et al. (2010) find that competence mismatches in the UK increase the workload of other staff, increase operating costs, and delay product development. On the other hand, Kampelmann and Rycx (2012) investigate the Flemish employee-employer data and find that over-qualification raises productivity. Research of this kind also took place on the national level, where it was argued that mismatches would likely lead to higher structural unemployment (Olitsky, 2008; Skott and Auerbach, 2019). Using US data, Slonimczyk (2009) finds that a substantial fraction (11\% for men and $32 \%$ for women) of the increase in wage dispersion during the 1973-2002 period was due to the increase in over-qualification rates and over-qualification premium. Along the same line of reasoning, Budría and Moro Egido (2005) use Spanish data to show that the incidence of mismatch contributes to increase wage differences within education groups by driving a wedge between matched and mismatched workers. Bevan and Cowling (2007) compared EU-15 countries between 1996 and 2000 waves of European Working Conditions Survey and found an overall reduction in the rate of over-skilling from 8.8 to $7.4 \%$, respectively. Differences in over-skilling among EU-15 were attributed to differences in educational systems, especially to a degree to which students can voluntarily prolong education, and different success rates of reforms to decrease such a mismatch. More recently, Škrinjarić and Domadenik (2019) used a sample of Croatian firms to show that mismatches in competences such as basic algebra, collectedness, conflict resolution and presentation, and motivation and organization were all negatively associated in explaining the variation of firm performance, with motivation and organization having the most significant effect.

From 2013 onwards, international comparisons were mainly based on Programme for the International Assessment of Adult Competencies (PIAAC) survey data, as it covers more countries, obtains larger sample sizes per country, and extends the depth and range of measured skills to include literacy, numeracy, and problem solving in technology-rich environments. Owing to its nature, most of the studies using PIAAC data are focused on the individual labor market outcomes and returns to education and/or skills. Notable exceptions are McGowan and Andrews (2017), who analyze the link between skill and qualification mismatch and labor productivity by combining PIAAC and industry data for 19 OECD countries. Their main results show that a higher competence mismatch is associated with lower labor productivity, with over-skilling and under-qualification accounting for most of these impacts.

In conclusion, competence mismatch remains one of the most under-utilized topics in competence literature. Alignment of competences sought by employers and those developed by employees is one of the key challenges of any economy, particularly given the increasing pace of digitization and decreasing the shelflife of existing competence inventories. Key challenges here are ensuring representativeness of results and competence tracking over time. Regarding the former, most analyses were concentrated on early graduates and on firms from the ICT sector, which are above-average in terms of firm efficiency distribution. The most important source of data comes from individually collected, project-level datasets, often concentrating on only a specific area. Instead, this type of research should receive national support to achieve representativeness and these results should then be used to align educational and training curricula to meet current labor market requirements. Furthermore, these nationally representative datasets should also contain a longitudinal dimension, which would allow for a dynamic analysis of mismatches and increase the validity of impact evaluations of such policies.

\section{Conclusion}

The fourth industrial revolution shall continue to increasingly demand a broad spectrum of new or updated competences for markets to function effectively. Simple and monotonous processes are being automated at an increasing pace, while other cognitive processes become more complex and intertwined, thus shortening the shelf-life of employees' competences. This is already recognized by numerous organizations, governments, and firms worldwide, who have acted towards equipping their workforce with contemporary competences required by the labor market. World Economic Forum (2016) estimates that about two thirds of global multi-national organizations tend to invest in the reskilling of current employees as part of their future workforce planning efforts. This is also backed up by initiatives such as the new OECDs' PIAAC framework, designed to assess meta-level competences and suggest areas for possible improvements.

Competence models are a descriptive tool that identifies competences needed to perform effectively in an organization (ChungHerrera et al., 2003; Hecklau et al., 2016), and they are also important for integrating education and training with the needs of the labor market, thus promoting mobility for individuals, especially for workers faced with job insecurity (Van der Klink and Boon, 2002).

Today, almost every organization uses some form of competence-based management, especially those with separate human resource departments. Simplicity and concreteness of competences as the common language of the whole organization makes them understandable to all employees, regardless of their position in the hierarchy or level of education, and therefore allows for a very concrete way of expressing organizational culture and values (Green, 1999; Kurz and Bartram, 2002). In addition to allowing the assessment of individuals' strengths and weaknesses, competence-based models enable the assessment of overall human potential and emphasize the areas in need of further development, thus becoming bases for education and training; coupled with a rewarding scheme, these models play an important role in directing and modifying individuals' behavior. However, as described in section "Limitations in competence 
measurement and analysis", there is still confusion and disagreement about what exactly competences are and how to accurately measure them-inconsistent, unmeasurable, discriminating, too numerous, and poorly classified competences resulted in many bad practical models. Although some indicators can already be measured by existing data, much must be done to improve established data sources and to create new ones that provide further insights in important competence dimensions. What is particularly missing in current analyses are longitudinal datasets, which would allow insights into competence development and requirement trends and would also reduce bias in estimating their effect on individual and organizational outcomes.

Misalignment of competence requirement and development has adverse effects not only on individuals and organizations but also on the society as a whole and more attention needs to be directed, both from the academic and policy-making sector, in identifying causes and proposing solutions to this issue. The first step in this direction involves defining which competences are considered crucial to modern-day organizations (employers), given their current needs in maintaining high competitiveness and business performance, but also looking in the future and anticipating the new trends set forth by the increased digitization process. The following step involves discovering reasons behind the existence and persistence of competence mismatch on the labor market. This is where we turn to the other side of the labor market, the individuals (employees), and assess their current development level of those competences deemed highly important to employers. After that, one needs to establish a sound methodology to measure the degree of this proximity (or mismatch) and assess how it affects both sides of the labor market: organizations in terms of their profitability and productivity, and individuals in terms of their employability and wages. Only after, and if, this competence proximity is found to significantly affect these outcomes, one may advise important policy recommendations for their better alignment and reduction of mismatch. Adult learning, work-based training, and training in the context of active labor market policies for the unemployed are also deemed important to prevent competence obsolescence and upgrade competence inventories considering new technology-driven requirements.

\section{Data availability}

This project contained no data.

Received: 9 June 2021; Accepted: 12 January 2022;

Published online: 25 January 2022

\section{References}

Adamchik VA, Hyclak TJ, Sedlak P, Taylor LW (2019) Wage returns to english proficiency in Poland. J Labor Res 40:276-295

Ahn YH, Annie RP, Kwon H (2012) Key competencies for US construction graduates: Industry perspective. J Prof Iss Eng Educ Pract 138(2):123-130

Allegrante JP, Moon RW, Auld ME, Gebbie KM (2001) Continuing-education needs of the currently employed public health education workforce. Am J Public Health 91(8):1230-1234

Allen J, Van der Velden RKW (2001) Educational mismatches versus skill mismatches: effects on wages, job satisfaction, on-the-job search. Oxford Econ Paper 53(3):434-452

Allen J, Arnesen CA, Calmand J, Frontini M, Paul JJ, Rostan M, Schomburg H, Storen LA, Teichler U, Van der Velden RKW (2007) The flexible professional in the knowledge society: general results of the REFLEX project. Research Centre for Education and the Labour Market. Maastricht University, Maastricht, Netherlands

Allen JP, Levels M, Van der Velden RKW (2013) Skill mismatch and skill use in developed countries: evidence from the PIAAC study. No. 017. Research Centre for Education and the Labour Market. Maastricht University, Maastricht, Netherlands
American Compensation Association (1996) The role of competencies in an integrated HR strategy. Am Compen Assoc J 5(2):6-21

Ananiadou K, Jenkins A, Wolf A (2004) Basic skills and workplace learning: What do we actually know about their benefits? Stud Contin Educ 26(2):289-308

Appelbaum E, Bernhardt A, Murnane RJ (2003) Low-wage America: how employers are reshaping opportunity in the workplace. Russell Sage Foundation

Azevedo A, Apfelthaler G, Hurst D (2012) Competency development in business graduates: an industry-driven approach for examining the alignment of undergraduate business education with industry requirements. Int J Manage Education 10(1):12-28

Badillo-Amador L, García-Sánchez A, Vila LE (2005) Mismatches in the spanish labor market: Education vs. competence match. Int Adv Econ Res 11(1):93-109

Bai X, Chang J (2015) Corporate social responsibility and firm performance: The mediating role of marketing competence and the moderating role of market environment. Asia Pacific J Manag 32(2):505-530

Bailey L, Ingimundardottir G (2015) International employability: stakeholder attitudes at an International University in Malaysia. J Teach Learn Grad Employab 6(1):44-55

Barone C, Van der Werfhorst HG (2011) Education, cognitive skills and earnings in comparative perspective. Int Sociol 26(4):483-502

Belasen AT, Rufer R (2007) Building a competency-based MBA from the ground up: curriculum design and program delivery. In: Academy of Management Proceedings, Academy of Management, Briarcliff Manor, New York. pp. 1-6

Benson GS, Lawler III EE (2011) Raising skill demand: Generating good jobs. In: Finegold D, Gatta M, Salzman H, Schurman SJ (eds.) Transforming the US workforce development system. Labor and employment relations association, Champaign, IL, pp. 87-109

Bevan S, Cowling M (2007) Job matching in the UK and Europe. The Work Foundation/UK Commission for Employment and Skills, London

Biesma RG, Pavlova M, van Merode GG, Groot W (2007) Using conjoint analysis to estimate employers preferences for key competencies of master level Dutch graduates entering the public health field. Econ Educ Rev 26(3):375-386

Biesma RG, Pavlova M, Vaatstra R, van Merode GG, Czabanowska K, Smith T, Groot W (2008) Generic versus specific competencies of entry-level public health graduates: employers' perceptions in Poland, the UK, the Netherlands. Adv Health Sci Educ 13(3):325-343

Bird B (1995) Towards a theory of entrepreneurial competency. Advances in entrepreneurship, firm emergence and growth 2(1):51-72

Bishop JH, Mane F (2004) The impacts of career-technical education on high school labor market success. Econ Educ Rev 23(4):381-402

Böhlmark A (2003) Over-and undereducation in the Swedish labour market. Incidence, wage effects and characteristics 1968-2000. Swedish Institute for Social Research (SOFI). Stockholm University, Stockholm, Sweden

Boyatzis RE (1982) The competent manager: a model for effective performance John Wiley \& Sons, New York, NY

Boyatzis RE (2008) Competencies in the $21^{\text {st }}$ century. J Manag Dev 27(1):5-12

Büchel F, Mertens A (2004) Overeducation, undereducation, the theory of career mobility. Appl Econ 36(8):803-816

Budría S, Moro Egido A (2005) Education, over-education and wage inequality: evidence for Spain. CEEAplA Working Paper Series No. 06/2005

Casner-Lotto J, Barrington L (2006) Are they really ready to work? Employers' perspectives on the basic knowledge and applied skills of new entrants to the 21st century US workforce. Partnership for 21st Century Skills, Washington, DC

Cheng MI, Dainty AR, Moore DR (2005) What makes a good project manager? Hum Resour Manag J 15(1):25-37

Chiru C, Ciuchete SG, Lefter GG, Paduretu E (2012) A cross country study on university graduates key competencies. an employer's perspective. Proc-Soci Behav Sci 46:4258-4262

Chung-Herrera BG, Enz CA, Lankau MJ (2003) Grooming future hospitality leaders: a competencies model. Cornell hotel and restaurant administration quarterly, Human Resources, pp. 1-25

Cowan DT, Wilson-Barnett DJ, Norman IJ, Murrells T (2008) Measuring nursing competence: development of a self-assessment tool for general nurses across Europe. Int J Nurs Stud 45(6):902-913

Crebert G, Bates M, Bell B, Patrick C, Cragnolini V (2004) Developing generic skills at university, during work placement and in employment: Graduates' perceptions. High Educ Res Dev 23(2):147-165

Čiarnienè R, Vilmantè K, Milita V (2010) Development of students' competencies: comparable analysis. Econ Manage 15:436-443

Dearden L, McIntosh S, Myck M, Vignoles A (2002) The returns to academic and vocational qualifications in Britain. Bull Econ Res 54(3):249-274

De Anda RM, Hernandez PM (2008) Literacy skills and earnings: race and gender differences. Rev Black Polit Econ 34(3):231-243 
De Vos A, De Hauw S, Van, der Heijden BI (2011) Competency development and career success: The mediating role of employability. J Vocat Behav 79(2):438-447

Delamare le Deist F, Winterton J (2005) What is competence? Hum Resour Dev Int $8(1): 27-46$

Desjardins R, Rubenson K (2011) An analysis of skill mismatch using direct measures of skills. OECD Education Working Papers No. 63

Dickerson A, Green F (2004) The growth and valuation of computing and other generic skills. Oxf Econ Pap 56(3):371-406

Dreyfus CR (2008) Identifying competencies that predict effectiveness of R\&D managers. J Manag Dev 27(1):76-91

Felstead A, Gallie D, Green F, Zhou Y (2007) Skills at Work in Britain, 1986 to 2006. ESRC Centre on Skills, Knowledge and Organisational Performance

Ferrari R (2015) Writing narrative style literature reviews. Med Writ 24(4):230-235

Finegold D, Notabartolo AS (2010) 21st century competencies and their impact: An interdisciplinary literature review. Board on Training and Assessment, Washington

Forth J, Mason G (2006) Do ICT skills shortages hamper firms' performance? Evidence from UK benchmarking surveys. National Institute of Economic and Social Research, London

Gabe T, Stolarick K, Abel JR(2012) Rural areas lag behind in key workforce skills. Choices: the magazine of food, farm and resource 28(2):12

García-Aracil A, Van der Velden R (2008) Competencies for young European higher education graduates: labor market mismatches and their payoffs. High Educ 55(2):219-239

Gerli F, Gubitta P, Tognazzo A (2011) Entrepreneurial competencies and firm performance: an empirical study. VIII International Workshop on Human Resource Management. Seville, Spain

Gokkaya O, Ozbag GK (2015) Lining core competence, innovation and firm performance. J Bus Res Turk 7(1):90-102

Green BN, Johnson CD, Adams A (2006) Writing narrative literature reviews for peer-reviewed journals: secrets of the trade. J Chiropr Med 5(3):101-117

Green DA, Riddell WC (2013) Ageing and literacy skills: evidence from Canada, Norway and the United States. Labour Econ 22(2):16-29

Green P (1999) Building robust competencies: linking human resource systems to organizational strategies. Jossey-Bass, San Francisco

Green F, McIntosh S (2007) Is there a genuine under-utilization of skills amongst the over-qualified? Appl Econ 39(4):427-439

Green F, McIntosh S, Vignoles A (2002) The utilization of education and skills: evidence from Britain. The Manchester School 70(6):792-811

Grzybowska K, Łupicka A (2017) Key competencies for Industry 4.0. Econ Manag Innov 1(1):250-253

Haider S, Solon G (2006) Life-cycle variation in the association between current and lifetime earnings. Am Econ Rev 96(4):1308-1320

Hanushek EA, Rivkin SG (2012) The distribution of teacher quality and implications for policy. Annu Rev Econ 4(1):131-157

Hanushek EA, Schwerdt G, Wiederhold S, Woessmann L (2015) Returns to skills around the world: evidence from PIAAC. Eur Econ Rev 73:103-130

Hazlina Ahmad N, Ramayah T, Wilson C, Kummerow L (2010) Is entrepreneurial competency and business success relationship contingent upon business environment? A study of Malaysian SMEs. Int J Entrep Behav Res 16(3):182-203

Hecklau F, Galeitzke M, Flachs S, Kohl H (2016) Holistic approach for human resource management in Industry 4.0. Procedia CIRP 54:1-6

Heijke H, Meng C, Ramaekers G (2003) An investigation into the role of human capital competences and their pay-off. Int J Manpow 24(7):750-773

Hodges D, Burchell N (2003) Business graduate competencies: employers' views on importance and performance. Asia-Pac J Coop Educ 4(2):16-22

Husain MY, Mokhtar SB, Ahmad AA, Mustapha R (2010) Importance of employability skills from employers' perspective. Procedia-Soc Behav Sci 7:430-438

Jackson D (2009) Profiling industry-relevant management graduate competencies: the need for a fresh approach. Int J Manag Educ 8:85-98

Jackling B, De Lange P (2009) Do accounting graduates' skills meet the expectations of employers? A matter of convergence or divergence. Account Educ 18(4):369-385

Jamshidi MHM, Rasli A, Yusof R (2012) A research design to predict HR managers and professionals' competencies of universities. J Basic Appl Sci Res 2(6):5694-5702

Kagermann H, Helbig J, Hellinger A, Wahlster W (2013) Surveillance samples for the design project industry 4.0: German design as production standard; conclusion report of the work industry 4.0. [Umsetzungsempfehlungen für das Zukunftsprojekt Industrie 4.0: Deutschlands Zukunft als Produktionsstandort sichern; Abschlussbericht des Arbeitskreises Industrie 4.0]. Frankfurt: Forschungsunion

Kampelmann S, Rycx F (2012) The impact of educational mismatch on firm productivity: Evidence from linked panel data. Econ Educ Rev 31(6):918-931

Kelly E, O'Connell PJ, Smyth E (2010) The economic returns to field of study and competencies among higher education graduates in Ireland. Econ Educ Rev 29(4):650-657
Kim J, Lee CY, Cho Y (2016) Technological diversification, core-technology competence, firm growth. Res Policy 45(1):113-124

Kirby S, Riley R (2006) The returns to general versus job-specific skills: The role of communication and information technology. National Institute for Economic and Social Research, London

Kreitner S, Leet TL, Baker EA, Maylahn C, Brownson RC (2003) Assessing competencies and training needs for public health professionals managing chronic disease prevention programs. J Public Health Manag Pract 9(4):284-290

Kucel A, Vilalta-Bufi M, Robert P (2011) Graduate labor mismatch in Central and Eastern Europe. Working Paper No. 259. Universitat de Barcelona: Espai de Recerca en Economia

Kurz R, Bartram D (2002) Competency and Individual Performance: Modelling the World of Work. In: Robertson IT, Callinan M, Bartram D (eds.) Organizational effectiveness: the role of psychology. John Wiley, Chichester, pp. 225-255

Kusumastuti D (2014) Identifying competencies that predict effectiveness of disaster managers at local government. Int J Soc Syst Sci 6(2):159-176

Lazarova M, Taylor S (2009) Boundaryless careers, social capital, knowledge management: Implications for organizational performance. J Organ Behav 30(1):119-139

Leoni R (2011) Employability of graduates and development of competencies: mind the gap and mind the step! Empirical evidence for Italy. Paper presented at the DEHEMS Conference, Vienna, November 22-23

Leoni R (2012) Workplace design, complementarities among work practices, the formation of key competencies: evidence from Italian employees. ILR Rev 65(2):316-349

Le Mouel M, Squicciarini M (2015) Cross-country estimates of employment and investment in organisational capital: a task-based methodology using the PIAAC database. DIW Discussion Papers No. 1522, Berlin, Germany

Lichtenberg JW, Portnoy SM, Bebeau MJ, Leigh IW, Nelson PD, Rubin NJ, Smith IL, Kaslow NJ (2007) Challenges to the assessment of competence and competencies. Prof Psychol Res Pract 38(5):474-478

Lloyd C, Payne J (2008) What is a skilled job? Exploring worker perceptions of skill in two UK call centers. SKOPE Research Paper No. 81. ESRC Centre on Skills, Knowledge and Organisational Performance, Cardiff

Lokshin B, Van Gils A, Bauer E (2009) Crafting firm competencies to improve innovative performance. Eur Manag J 27(3):187-196

Mahmood K (2003) A comparison between needed competencies of academic librarians and LIS curricula in Pakistan. Electr Libr 21(2):99-109

Man TW, Lau T, Chan KF (2002) The competitiveness of small and medium enterprises: A conceptualization with focus on entrepreneurial competencies. J Bus Ventur 17(2):123-142

Man TW, Lau T (2005) The context of entrepreneurship in Hong Kong: An investigation through the patterns of entrepreneurial competencies in contrasting industrial environments. J Small Bus Enterpr Dev 12(4):464-481

Markman GD (2014) Entrepreneurs' competencies. In: Baum JR, Frese M, Baron RA (eds) Psychol Entrepreneur. Psychology Press, New York, NY, pp. 99-124

Mason G, Williams G, Cranmer S (2006) Employability skills initiatives in higher education: What effects do they have on graduate labour market outcomes? National Institute of Economic and Social Research, London

Mavromaras K, McGuinness S, Fok YK (2009) Assessing the incidence and wage effects of overskilling in the Australian labour market. Econ Record 85(268):60-72

Maxwell NL (2006) The working life: the labor market for workers in low skilled jobs. W.E. Upjohn Institute for Employment Research, Kalamazoo, MI

McClelland DC (1973) Testing for competence rather than for 'intelligence'. Am Psychol 28(1):1-14

McDougall R (2015) Reviewing literature in bioethics research: increasing rigour in non-systematic reviews. Bioethics 29(7):523-528

McGowan MA, Andrews D (2017) Labor market mismatch and labor productivity: evidence from PIAAC Data. In: Skill mismatch in labor markets. Emerald Publishing Limited, Bingley, pp. 199-224

Mikkelsen A, NybØ G, GrØnhaug K (2002) Exploring the impact of deregulation on HRM: the case of the Norwegian energy sector. Int J Hum Resour Manag 13(6):942-957

Mitchelmore S, Rowley J (2010) Entrepreneurial competencies: a literature review and development agenda. Int J Entrepreneur Behav Res 16(2):92-111

Moore DR, Cheng M-I, Dainty ARJ (2002) Competence, competency and competencies: performance assessment in organisations. Work Study 51(6):314-319

Mora JG, García-Aracil A, Vila LE (2007) Job satisfaction among young European higher education graduates. High Educ 53(1):29-59

Murnane RJ, Willett JB, Duhaldeborde Y, Tyler JH (2000) How important are the cognitive skills of teenagers in predicting subsequent earnings? J Policy Anal Manag 19(4):547-568

Murray TS, Owen E, McGaw B (2005) Learning a living: first results of the adult literacy and life skills survey. Statistics Canada and the Organization for Cooperation and Development, Ottawa 
Nicolescu L, Paun C (2009) Relating higher education with the labour market: graduates' expectations and employers' requirements. Tert Educ Manag 15(1):17-33 Nielsen CP (2007) Immigrant overeducation: evidence from Denmark. The World Bank OECD (2005) The definition and selection of key competences. Executive Summary

Olitsky N (2008) The procyclicality of mismatches. University of MassachusettsDartmouth, mimeo

Owen E (2001) What key skills do employers need? J Geogr High Education 25(1):121-126

Ozkaya HE, Droge C, Hult GTM, Calantone R, Ozkaya E (2015) Market orientation, knowledge competence, innovation. Int J Res Market 32(3):309-318

Quintini G (2011) Over-qualified or under-skilled. A review of existing literature. Working paper No. 121. OECD Social, employment and migration

Pan P, Perera H (2012) Market relevance of university accounting programs: Evidence from Australia. Account Forum 36(2):91-108

Prahalad CK, Hamel G (1990) The core competence of the corporation. Harv Bus Rev 68(3):79-91

Psacharopoulos G, Schlotter M (2010) Skills for employability, economic growth and innovation: monitoring the relevance of education and training systems. European Expert Network on Economics of Education (EENEE) analytical report, No. 6, Munich, Germany

Rieckmann M (2012) Future-oriented higher education: which key competencies should be fostered through university teaching and learning? Futures 44(2):127-135

Robertson IT, Callinan M, Bartram D (2003) Organizational effectiveness: the role of psychology. John Wiley \& Sons, New York, NY

Rodriguez D, Patel R, Bright A, Gregory D, Gowing MK (2002) Developing competency model to promote integrated human resource practices. Hum Resour Manag 41(1):309-324

Ryan C, Sinning M (2009) Skill matches to job requirements. National Centre for Vocational Education Research, Adelaide, Australia

Saniuk A, Saniuk S, Caganova D, Cambal M (2014) Control of strategy realization in metallurgical production. In: Proceedings of the 23rd International Conference on Metallurgy and Materials-METAL. Tanger, Czech Republic

Secretary's Commission on Achieving Necessary Skill (SCANS) (2001) Skills and Task for Jobs: A SCANS Report for America 2000. U.S. Department of Labour

Shury J, Winterbotham M, Davies B, Oldfield K, Spilsbury M, Sonstable S (2010) National employer skills survey for England 2009: main report: evidence report 23. IFF Research and UK Commission for Employment and Skills

Skott P, Auerbach P (2019) Wage Inequality and Skill Asymmetries. In: Setterfield $M$ (ed.) Interactions in analytical political economy: theory, policy and applications. Armonk, New York, NY, pp. 27-55

Slonimczyk F (2009) Skill mismatch and wage inequality in the US. Open Access Dissertations, University of Massachusetts Amherst

Song M, Droge C, Hanvanich S, Calantone R (2005) Marketing and technology resource complementarity: an analysis of their interaction effect in two environmental contexts. Strateg Manag J 26(3):259-276

Sonntag K, Schmidt-Rathjens C (2004) Competence models - Error factors in HR management?. A strategy and evidence-based approach to competency modeling. [Kompetenzmodelle-Erfolgsfaktoren im HR-Management?. Ein strategie-und evidenzbasierter Ansatz der Kompetenzmodellierung]. Personalführung 37 , pp. $18-26$

Sparrow PR, Bognanno M (1993) Competency requirement forecasting: issues for international selection and assessment. Int J Select Assess 1(1):50-58

Spencer L, Spencer S (1993) Competence at work: a model for superior performance. Wiley, New York, NY

Spendlove M (2007) Competencies for effective leadership in higher education. Int J Educ Manag 21(5):407-417

Spenner KI (1990) Skill: meanings, methods, measures. Work Occupat 17(4):399-421

Spitz-Oener A (2006) Technical change, job tasks, rising educational demands: Looking outside the wage structure. J Labor Econ 24(2):235-270

Srhoj S, Škrinjarić B, Radas S (2021) Bidding against the odds? The impact evaluation of grants for young micro and small firms during the recession. Small Bus Econ 56(1):83-103

Stevens PA (2007) Skill shortages and firms' employment behaviour. Labour Econ 14(2):231-249

Škrinjarić B, Domadenik P (2019) Examining the role of key competences in firm performance. Int J Manpow 41(4):391-416
Van der Heijde CM, Van Der Heijden BI (2006) A competence-based and multidimensional operationalization and measurement of employability. Hum Resour Manag 45(3):449-476

Van der Klink M, Boon J (2002) The investigation of competencies within professional domains. Hum Resour Dev Int 5(4):411-424

Van Loo JB, Toolsema B (2005) The empirical determination of key skills from an economic perspective. Educ Econ 13(2):207-221

Verhaest D, Omey E (2006) The impact of overeducation and its measurement. Soc Indic Res 77(3):419-448

Verhofstadt E, De Witte H, Omey E (2007) Higher educated workers: better jobs but less satisfied? Int J Manpow 28(2):135-151

Vieira JAC (2005) Skill mismatches and job satisfaction. Econ Lett 89(1):39-47

Wang Y, Lo HP, Yang Y (2004) The constituents of core competencies and firm performance: evidence from high-technology firms in China. J Eng Technol Manag 21(4):249-280

White R (1959) Motivation reconsidered: the concept of competence. Psychol Rev 66:279-333

Wilton N (2008) Business graduates and management jobs: an employability match made in heaven? J Educ Work 21(2):143-158

World Economic Forum (2016) The future of jobs: employment, skills and workforce strategy for the fourth industrial revolution. World Economic Forum

Yang MY, You M, Chen FC (2005) Competencies and qualifications for industrial design jobs: implications for design practice, education, student career guidance. Design Stud 26(2):155-189

Yusof HM, Mustapha R, Mohamad SAMS, Bunian MS (2012) Measurement model of employability skills using confirmatory factor analysis. Procedia-Soc Behav Sci 56:348-356

Zehrer A, Mossenlechner C (2009) Key competencies of tourism graduates: the employer's point of view. J Teach Travel Tour 9(3-4):266-287

\section{Competing interests}

The author declares no competing interests.

\section{Ethical approval}

Ethical approval is not applicable to this research.

\section{Informed consent}

This article does not contain any studies with human participants performed by any of the authors.

\section{Additional information}

Correspondence and requests for materials should be addressed to Bruno. Škrinjarić.

Reprints and permission information is available at http://www.nature.com/reprints

Publisher's note Springer Nature remains neutral with regard to jurisdictional claims in published maps and institutional affiliations.

Open Access This article is licensed under a Creative Commons Attribution 4.0 International License, which permits use, sharing, adaptation, distribution and reproduction in any medium or format, as long as you give appropriate credit to the original author(s) and the source, provide a link to the Creative Commons license, and indicate if changes were made. The images or other third party material in this article are included in the article's Creative Commons license, unless indicated otherwise in a credit line to the material. If material is not included in the article's Creative Commons license and your intended use is not permitted by statutory regulation or exceeds the permitted use, you will need to obtain permission directly from the copyright holder. To view a copy of this license, visit http://creativecommons.org/ licenses/by/4.0/

(C) The Author(s) 2022 